\section{Response of Four Apple Cultivars to 1-Methylcyclopropene Treatment and Controlled Atmosphere Storage}

\author{
Jinhe Bai \\ Oregon State University, Mid-Columbia Agricultural Research and Extension \\ Center, Hood River, OR 97031
}

Elizabeth A. Baldwin ${ }^{1}$ and Kevin L. Goodner

U.S. Department of Agriculture, Agricultural Research Service, Citrus and Subtropical Products Laboratory, Winter Haven, FL 33881

\section{James P. Mattheis}

U.S. Department of Agriculture, Agricultural Research Service, Tree Fruit Research Laboratory, Wenatchee, WA 98801

\section{Jeffrey K. Brecht \\ Horticultural Sciences Department, University of Florida, Gainesville, FL 32611}

Additional index words. Malus sylvestris var. domestica, firmness, titratable acidity, volatile abundance, 1-MCP, CA

\begin{abstract}
Apples [Malus sylvestris (L.) Mill var. domestica (Borkh.) Mansf. ('Gala', 'Delicious', 'Granny Smith' and 'Fuji')], pretreated or nontreated with 1-methylcyclopropene (1-MCP, 0.6 to $1.0 \mu \mathrm{L} \cdot \mathrm{L}^{-1}$ for 18 hours at $20^{\circ} \mathrm{C}$ ), were stored in controlled atmosphere (CA, 1 to $1.5 \mathrm{kPa} \mathrm{O}_{2} ; 1$ to $2 \mathrm{kPa} \mathrm{CO}$ ) or in regular atmosphere (RA) for up to 8 months at $1^{\circ} \mathrm{C}$. Firmness, titratable acidity (TA), soluble solids content (SSC), and volatile abundance were analyzed every month directly or after transfer to air at $20^{\circ} \mathrm{C}$ for 1 week to determine effect of 1-MCP, storage atmosphere and storage time on apple quality immediately after cold storage and after simulated marketing conditions at $20^{\circ} \mathrm{C}$. The 1-MCP $\pm \mathrm{CA}$ treatments delayed ripening and prolonged storage life as indicated by delayed loss of firmness and TA in all four cultivars during storage. The 1-MCP \pm CA also slightly delayed loss of SSC for 'Gala' but had no effect on SSC levels for the other cultivars. There were differences among treatments for firmness and TA content [(1-MCP + RA) > CA] for 'Gala', 'Delicious', and 'Granny Smith' apples, but not for 'Fuji'. These differences were generally exacerbated after transfer of fruit to $20^{\circ} \mathrm{C}$ for 1 week. A combination of 1-MCP + CA was generally best [(1-MCP + CA $)>(1-\mathrm{MCP}+\mathrm{RA})$ or CA] for maintaining 'Delicious' firmness and TA. However, the treatments that were most effective at retaining TA and firmness also retained the least volatiles. The results indicate that the efficacy of 1-MCP and $\mathrm{CA}$ in maintaining apple quality factors is cultivar dependent and that $1-\mathrm{MCP}+\mathrm{RA}$ may be a viable alternative to $\mathrm{CA}$ for optimal eating quality for some cultivars.
\end{abstract}

The compound 1-methylcyclopropene (1$\mathrm{MCP})$ has been discovered to be a very effective inhibitor of ethylene action due to competitive binding on the ethylene receptor in plant tissue (Sisler et al., 1996; Sisler and Serek, 1999; Sisler and Wood, 1988). 1-MCP has been recently approved by the U.S. Environmental Protection Agency (2002) as a reduced-risk product for use on produce. Much research has been conducted in the last few years,

Received for publication 12 Jan. 2005. Accepted for publication 20 Mar. 2005. Mention of a trademark or proprietary product is for identification only and does not imply a guarantee or warranty of the product by the U.S. Department of Agriculture. The U.S. Department of Agriculture prohibits discrimination in all its programs and activities on the basis of race, color, national origin, gender, religion, age, disability, political beliefs, sexual orientation, and marital or family status. This material is based on work supported by the Washington Tree Fruit Research Commission.

${ }^{1}$ To whom reprint requests should be addressed; e-mail ebaldwin@citrus.usda.gov. which showed that 1-MCP decreased ethylene production; reduced respiration, softening, loss of titratable acidity, color change, and some physiological disorders; and increased storage life of apples (Blankenship and Dole, 2003; Watkins and Miller, 2004). 1-MCP has been considered a major breakthrough in apple storage technology.

The efficacy of 1-MCP depends on cultivar and storage condition of apple (Fan et al., 1999; Watkins et al., 2000) as well as harvest maturity (Mir et al., 2001). For example, the general range of 0.5 to $2.0 \mu \mathrm{L} \cdot \mathrm{L}^{-1} 1-\mathrm{MCP}$ is

effective to retard flesh softening in apples. treatment by 1-MCP(Fan and Mattheis, 1999; with $1-\mathrm{MCP}$ for $18 \mathrm{~h}$ at $20^{\circ} \mathrm{C}$ then stored at $1{ }^{\circ} \mathrm{C}$.

\begin{tabular}{|c|c|c|c|c|c|}
\hline \multirow[b]{2}{*}{ Cultivar } & \multirow{2}{*}{$\begin{array}{l}\text { Harvest } \\
\text { date } \\
(2001)\end{array}$} & \multirow{2}{*}{$\begin{array}{l}\text { 1-MCP } \\
\text { concn } \\
\left(\mu \mathrm{L} \cdot \mathrm{L}^{-1}\right)\end{array}$} & \multicolumn{2}{|c|}{$\begin{array}{c}\text { CA storage condition } \\
(\mathrm{kPa})\end{array}$} & \multirow{2}{*}{$\begin{array}{c}\text { Experiment } \\
\text { month }\end{array}$} \\
\hline & & & $\overline{\mathrm{O}_{2}}$ & $\overline{\mathrm{CO}_{2}}$ & \\
\hline Gala & 4 Sept. & 0.625 & 1 & 2 & 6 \\
\hline Delicious & 16 Oct. & 1.0 & 1 & 2 & 8 \\
\hline Granny Smith & 16 Oct. & 1.0 & 1.5 & 1 & 8 \\
\hline Fuji & 31 Oct. & 1.0 & 1.5 & 1 & 8 \\
\hline
\end{tabular}
physiological disorders developed with the combination (DeEll et al., 2005).

High firmness, appropriate sugar to acid ratio, and aroma profile are considered important parameters for apple eating quality. Since sugars, the major component in the soluble solids, do not change much during storage, delayed loss of firmness and acidity are the most important indicators for evaluating apple storage practices. Volatile compounds produced by apples constitute aroma, however instrumental analysis of volatiles has indicated that there is a loss of aroma after long-term storage and due to treatment by 1-MCP (Fan and Mattheis, 1999;

cultivars. Fruit were pretreated directly after harvest
For 'Empire' and 'Delicious' cultivars, softening was retarded when treated by $1-\mathrm{MCP}$ in the lower end of this range, while the higher end was necessary to get the same effect for 'McIntosh' and 'Law Rome' apples (Watkins et al., 2000). Inconsistencies in EthylBlock powder that occurred during the early years of production may make the concentration incorrect (Blankenship and Dole, 2003; Zanella, 2003), however, recent studies in apples indicate that $1.0 \mu \mathrm{L} \cdot \mathrm{L}^{-1} 1-\mathrm{MCP}$ is effective for most of the cultivars (Blankenship and Dole, 2003; Watkins and Miller, 2004).

Controlled atmosphere (CA) storage has been used for apple commercial storage for decades, and has been recognized as the most practical and effective supplement to proper temperature management for extending the shelf life of intact and fresh-cut fruits and vegetables. About $50 \%$ of the U.S. apple production is held in CA storage, with recommended CA conditions of 1 to $3 \mathrm{kPaO}_{2}$ and 1 to $5 \mathrm{kPa} \mathrm{CO}$ at $0{ }^{\circ} \mathrm{C}$ depending on the cultivar (Watkins et al., 2004).

It is not clear how use of 1-MCP on apples will interact with CA storage, and how CA storage of apples, with or without 1-MCP, compares with 1-MCP and subsequent air storage for optimal eating quality. Watkins et al. (2000) reported that the effects of 1-MCP are greater in CA than in regular air (RA) with 'McIntosh', 'Empire', 'Delicious', and 'Law Rome' apples, as also observed by DeLong et al. (2004) in 'Cortland' and 'McIntosh' apples. However, 1-MCP treatment maintained greater firmness and controlled scald of 'Granny Smith' apples regardless if in CA or RA (Zanella, 2003). Furthermore, a disorder, resembling external $\mathrm{CO}_{2}$ injuries, was observed on fruit treated with 1-MCP and subsequently stored in CA (Zanella, 2003). DeEll et al. (2005) compared the effects of standard CA and low $\mathrm{O}_{2}$ CA on storage quality of apples pretreated with or without 1-MCP. The results indicate that for 'Empire', 'Gala', and 'Delicious', there was no further quality benefit from combining low $\mathrm{O}_{2} \mathrm{CA}$ with 1-MCP. In addition, several 
Fan et al., 1999; Lurie et al., 2002; Rupasinghe etal., 2000). Whether 1-MCP treatment of apple is compatible with, or could replace CA storage for the best overall apple quality (considering the effect on apple flavor resulting from the retention of acids versus loss of volatiles), is still not clear. The literature contains several reports of the effect of 1-MCP on maintenance of apple firmness and sometimes acidity, and volatile losses when the fruit are stored in air (DeEll et al., 2002; Fan and Mattheis, 1999; Fan et al., 1999; Jaing and Joyce, 2002; Lurie et al., 2002; Mir et al., 2001; Rupasinghe et al., 2000). Some reports are of fruit in cold storage, ambient or combined cold followed by a simulated ambient marketing period. A few studies compared 1-MCP treatment of fruit stored in CA versus RA after cold storage compared to after a marketing period, for firmness and acidity, but not volatiles (DeEll et al., 2005; DeLong et al., 2004; Watkins et al., 2000; Zanella, 2003).

In this research, we investigated the responses of major northwest apple cultivars to $1-\mathrm{MCP}, \mathrm{CA}$, or $1-\mathrm{MCP}+\mathrm{CA}$ compared to apples stored in air. The objective of this study was to determine whether 1-MCP pretreatment and CA storage interact in terms of factors that affect apple eating quality, as determined by changes in firmness, titratable acidity, soluble solids content, and volatile abundance measured immediately after cold storage and after a week under simulated marketing conditions. Results will help industry make informed choices about use of 1-MCP in combination with storage atmosphere for optimal apple eating quality.

\section{Materials and Methods}

Early cultivar 'Gala'(harvested on 4 Sept.), midseason cultivars 'Delicious', 'Granny Smith' (harvested 16 Oct.) and late-ripening cultivar 'Fuji' (harvested 31 Oct.) apples ( $\mathrm{Ma}$ lus sylvestris (L.) Mill var. domestica (Borkh.) Mansf) were harvested randomly from commercial orchards located in Wenatchee, Wash., in 2001 at the pre-to early-climacteric stage, as determined by internal ethylene concentration (Williams and Patterson, 1962) except for 'Delicious'. Ethylene means \pm standard deviation $(\mathrm{n}=10)$ at harvest were $2.0 \pm 1.4$ for 'Gala', $2.3 \pm 1.6$ for 'Fuji', $19 \pm 17$ for 'Delicious', and undetectable of 'Granny Smith'. Starch means (on a 1 to 6 scale) were $3.7 \pm 1.2$ for 'Gala', $4.6 \pm 0.6$ for 'Fuji', $2.2 \pm 0.3$ for 'Delicious', and $2.0 \pm 0.1$ for 'Granny Smith'. For every cultivar, defect-free fruit were divided into two groups, one for 1-MCP treatment and another for nontreated control. Pretreatment of 1-MCP was immediately performed by exposing fruit to 1-MCP (SmartFresh, Rohm and Haas, Philadelphia, Pa.) at $20^{\circ} \mathrm{C}$ for $18 \mathrm{~h}$ at USDA Tree Fruit Research Laboratory in Wenatchee using a 230-L steel chamber with sufficient headspace to prevent development of anaerobic respiration during treatment. The initial concentration of 1-MCP was determined by gas chromatography (GC) calibrated with 1-butene (Gong et al., 2002), and was 0.6 $\mu \mathrm{L} \cdot \mathrm{L}^{-1}$ for 'Gala' and $1.0 \mu \mathrm{L} \cdot \mathrm{L}^{-1}$ for other cultivars. Preliminary work with $1-\mathrm{MCP}$ on these cultivars had determined the effective concentrations used in this study and the fact that the European protocol for 1-MCP-treated fruit is $0.6 \mu \mathrm{L} \cdot \mathrm{L}^{-1}$.

Both 1-MCP-treated and nontreated groups were further divided to two batches, one for CAstorage and another for regular atmosphere (RA) storage at $1{ }^{\circ} \mathrm{C}$ and $95 \% \mathrm{RH}$. The $\mathrm{CA}$ conditions were 1 to $1.5 \mathrm{kPa} \mathrm{O}$ and 1 to 2 $\mathrm{kPa} \mathrm{CO}_{2}$, depending on cultivar (Table 1). Optimal CA conditions and length of storage have previously been established for these cultivars (Kupferman, 2003; Mattheis et al., 1998; Plotto et al., 1997).

Immediately after 1 -MCP treatment, or every month after storage at $1{ }^{\circ} \mathrm{C}$, fruit were shipped overnight to the USDACitrus and Subtropical Products Laboratory in Winter Haven, Fla., with separate boxes for the 1-MCP-treated and nontreated fruit. Fruit temperatures were between 5 to $14{ }^{\circ} \mathrm{C}$ upon arrival. Every shipment included 40 fruit from each treatment and each cultivar, from which 20 fruit were immediately analyzed for the quality parameters upon arrival, and another 20 fruit were analyzed after storage at $20^{\circ} \mathrm{C}$ for 1 week, to simulate the marketing conditions.

Measurements were obtained using five composite replicates of four fruit each. Flesh firmness and soluble solids content (SSC) were measured for each individual fruit and averaged per replicate. The SSC was measured using a digital, temperature-compensated refractom- eter (model PR-101; Atago Co. Tokyo, Japan) with freshly prepared juice.

Flesh firmness was assessed with a penetrometer (FT 327; McCormick, Facchini, Alfonsine, Italy), equipped with a cylindrical plunger $11 \mathrm{~mm}$ in diameter. The measurement was obtained from the equatorial area where 16 mm-diameter peel discs had been removed.

Titratable acidity (TA) and $\mathrm{pH}$ were measured from $50 \mathrm{~g}$ of flesh tissue obtained from four fruit per replicate and $50 \mathrm{~mL}$ deionized water, blended at speed 4 for $45 \mathrm{~s}$ with a homogenizer (model PT 10/35; Brinkmann Instruments, Co., Switzerland). The homogenate was vacuum-filtered through a $25-$ to $50-\mu \mathrm{m}$ Büchner funnel. The filtrates $(20 \mathrm{~g})$ were measured for $\mathrm{pH}$ and then were titrated to $\mathrm{pH} 8.1$ with $0.1 \mathrm{~N} \mathrm{NaOH}$ using a Sage dispensing system (ATI Orion, Boston, Mass.), and the acidity was calculated as malic acid on a weight basis.

Volatile compounds were measured by headspace sampling [using an autosampler (NPS-2; Gerstel, Baltimore, Md.)] of tissue homogenate, and analyzed with a GC (model 6890; Agilent Technologies, Palo Alto, Calif.) equipped with a $0.53 \mathrm{~mm} \times 30 \mathrm{~m}$ polar Stabilwax capillary column $(1.0-\mu \mathrm{m}$ film thickness, Restek, Bellefonte, $\mathrm{Pa}$.) and a flame ionization detector (FID). Apple tissue (50 g) from four fruit per replicate was homogenized with 25 $\mathrm{mL}$ deionized water and $25 \mathrm{~mL}$ saturated $\mathrm{NaCl}$ solution (Bai et al., 2004). The homogenate (2

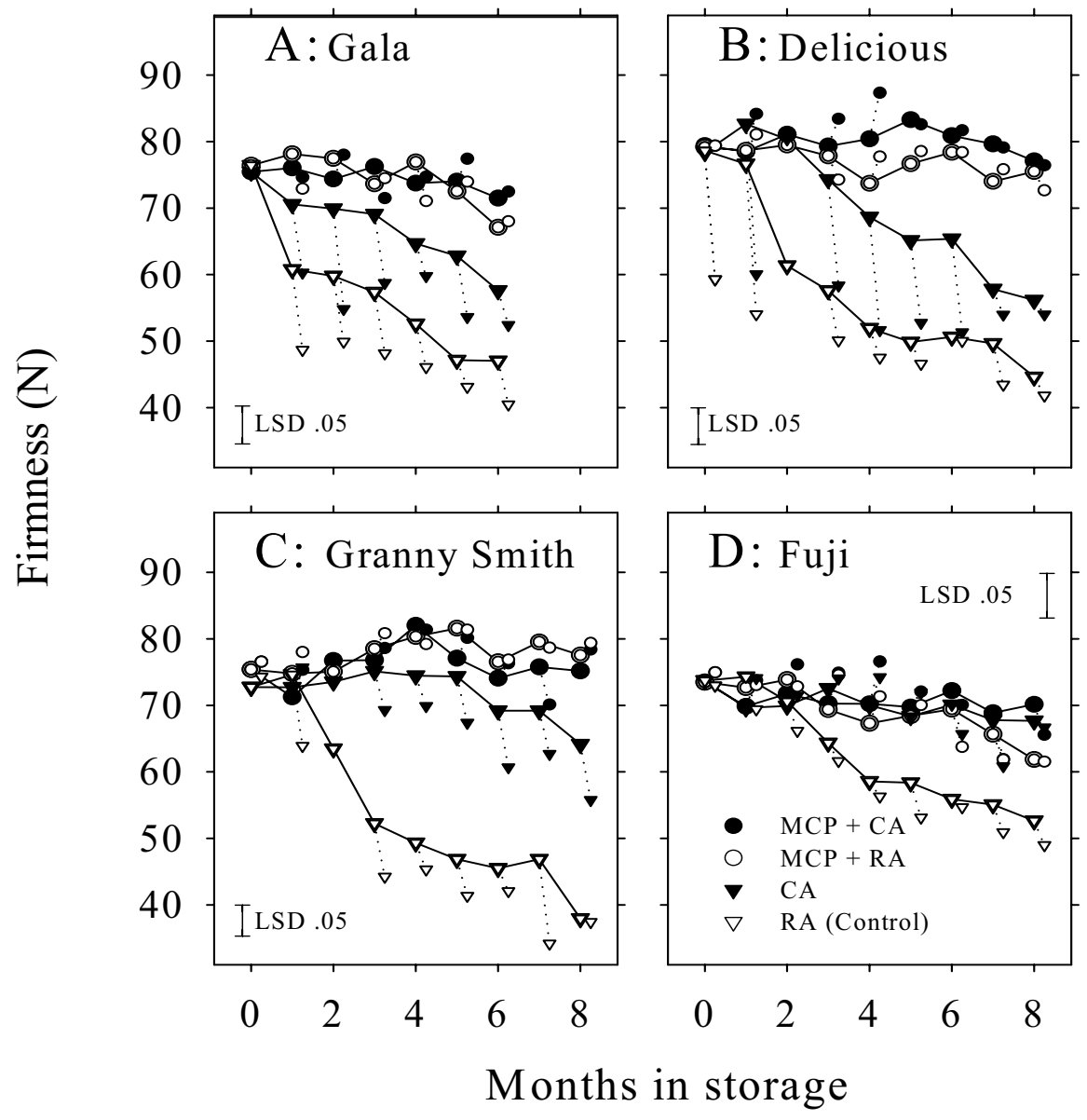

Fig. 1. Firmness of four apple cultivars treated with 1-MCP or not, and stored in CA or RA at $1{ }^{\circ} \mathrm{C}$ (solid line); subsamples were transferred to $20^{\circ} \mathrm{C}$ for an additional week (dotted line). 
$\mathrm{mL}$ ) was transferred to 20-mL glass vials sealed with a crimp-topped Teflon-silicone septum, flash frozen in liquid nitrogen and stored at later thawed under running tap water, then were incubated in an agitator at $500 \mathrm{rpm}$ and $40^{\circ} \mathrm{C}$ for $2 \mathrm{~min}$ before the headspace sample $(1 \mathrm{~mL})$ was taken from the vial and injected into the GC. The analysis conditions were: oven temperature held at $40^{\circ} \mathrm{C}$ for $6 \mathrm{~min}$, then raised to $180^{\circ} \mathrm{C}$ at a rate of $6^{\circ} \mathrm{C} \cdot \mathrm{min}^{-1}$. The injection port and detector were kept at 250 and $280^{\circ} \mathrm{C}$, respectively. For a general picture of volatile production, including unknown compounds, $-80^{\circ} \mathrm{C}$ before analysis. Frozen samples were

total volatile abundance is reported in FID area response units rather than absolute amounts of individual analytes.

A split-plot analysis of variance (PROC ANOVA, Version 8, SAS Institute, Cary, N.C.) was used for statistical analysis to determine the effect of 1-MCPvs. non-1MCP, CAvs. RA, storage duration ( 0 to 8 months), and before vs. after transfer to $20^{\circ} \mathrm{C}$ on SSC, flesh firmness, TA, and total volatile abundance. Means among each measurement were separated by the least significant difference at the $5 \%$ level (LSD 0.05). Regression analysis was carried out using PROC REG (SAS).

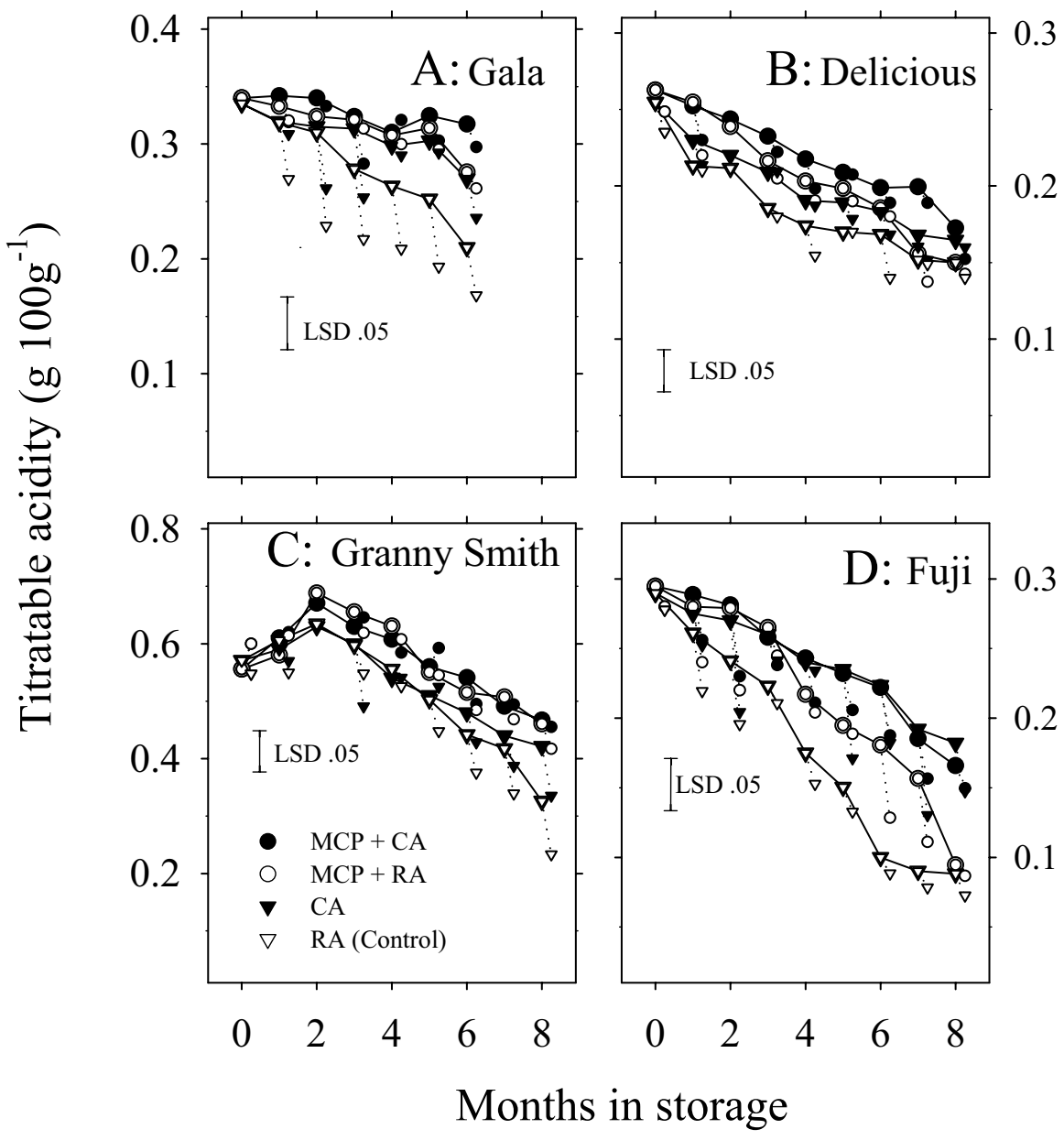

Fig. 2. Titratable acidity (TA) content of four apple cultivars treated with 1-MCP or not, and stored in CA or RA at $1{ }^{\circ} \mathrm{C}$ (solid line); subsamples were transferred to $20^{\circ} \mathrm{C}$ for 1 additional week (dotted line).

\section{Results and Discussion}

Firmness. 1-MCP and/or CA storage retarded the loss of firmness after the first 4 weeks of storage at $1{ }^{\circ} \mathrm{C}$, compared with the control for all four cultivars (Fig.1). Fruit treated with 1-MCP, regardless of storage atmosphere, remained firmer during storage at $1{ }^{\circ} \mathrm{C}$; however, 'Gala' and 'Delicious' lost firmness over time in CA or air if not treated with 1-MCP. 'Granny Smith', stored in CA, lost firmness after 5 months storage. 'Fuji' is the only cultivar for which CAmaintained fruit firmness similarly to1-MCP in RA. However, over all of the four cultivars, fruit stored in CA generally maintained firmer flesh than that of control fruit stored in RA after the first 2 months (Fig. 1). These results are not surprising as it has been reported that 1-MCP-treated apples maintained firmness for "Redchief Delicious' (Jayanty et al., 2004; Mir et al., 2001), 'Fuji', 'Gala', 'Gingergold', 'Jonagold', 'Delicious' (Fan etal., 1999), 'Golden Delicious'(Jiang and Joyce, 2002), 'Cortland', and 'Empire' apples (DeEll etal., 2002) in RA storage; for 'Empire', 'Gala' and 'Delicious' in CA storage (DeEll et al., 2005); for 'Granny Smith' (Zanella, 2003), 'McIntosh', 'Empire', 'Law Rome' (Watkins et al., 2000), 'Cortland', and 'McIntosh'(DeLong et al., 2004) in CA and RA storage. DeLong et al. (2004) and Watkins et al. (2000) found that the combination of 1-MCP and CA was more effective in maintaining firmness than when 1-MCP-treated apples were stored in air as was found in this study.

When the fruit were transferred from $1{ }^{\circ} \mathrm{C}$ to $20{ }^{\circ} \mathrm{C}$ storage for 1 week, further firmness loss occurred in the control for all four cultivars, with average losses of $13 \%, 11 \%, 9 \%$, and $4 \%$ in 1 week for 'Gala', 'Delicious', 'Granny Smith', and 'Fuji', respectively (Fig. 1). The firmness losses in CA-stored fruit after transfer to $20{ }^{\circ} \mathrm{C}$ were similar to those in control fruit for 'Gala', 'Delicious', and 'Granny Smith', but no significant decrease was observed for 'Fuji'. Treatments with 1-MCP prevented the rapid firmness loss upon transfer of fruit to room temperature, regardless of storage atmosphere. Following reports support the 1 -MCP prevention to firmness loss in shelf life at room temperatures: DeEll et al. (2005) with 'Gala' and 'Delicious' in CA, Watkins et al. (2000) with 'Delicious' and Zanella (2003) with 'Granny Smith' in RA and CA.

Table 2. F value, significant levels and CV (\%) from analysis of variance performed on firmness, titratable acidity (TA), and volatile abundance (VA) of four apple cultivars pretreated or not pretreated with 1-MCP, stored in CA or RA at $1{ }^{\circ} \mathrm{C}$ for 6 to 8 months, and then with or without transfer to $20^{\circ} \mathrm{C}$ for 1 additional week.

\begin{tabular}{|c|c|c|c|c|c|c|c|c|c|c|c|c|c|c|c|c|}
\hline \multirow{2}{*}{$\begin{array}{l}\text { Analysis } \\
\text { of variance }\end{array}$} & \multicolumn{4}{|c|}{ Gala } & \multicolumn{4}{|c|}{ Delicious } & \multicolumn{4}{|c|}{ Granny Smith } & \multicolumn{4}{|c|}{ Fuji } \\
\hline & df & Firmness & TA & VA & df & Firmness & TA & VA & df & Firmness & TA & VA & df & Firmness & TA & VA \\
\hline 1-MCP (M) & 1 & $1035.31^{* * *}$ & $284.11^{* * *}$ & $394.22^{* * *}$ & 1 & $1696.52^{* * *}$ & $60.52^{* *}$ & $312.99^{* * *}$ & 1 & $1816.08^{* * *}$ & $137.89^{* * *}$ & $25.23^{* * *}$ & 1 & $62.59^{* * *}$ & $42.01^{* *}$ & $88.37^{* *}$ \\
\hline $\mathrm{CA}(\mathrm{C})$ & 1 & $102.57^{* * *}$ & $111.1^{* * *}$ & $212.17^{* * *}$ & 1 & $171.86^{* * *}$ & $17.45^{* *}$ & $128.77^{* * *}$ & 1 & $455.36^{* * *}$ & 2.88 & $116.16^{* *}$ & 1 & $94.52^{* *}$ & $163.55^{* *}$ & $299.67^{* *}$ \\
\hline Duration (D) & 6 & $16.94^{* * *}$ & $38.27^{* *}$ & $98.58^{* *}$ & 8 & $34.57^{* *}$ & $65.16^{* *}$ & $20.81^{* * *}$ & 8 & $45.67^{* *}$ & $50.79^{* * *}$ & $36.64^{* *}$ & 8 & $32.59^{* *}$ & $141.73^{* *}$ & $66.77^{* *}$ \\
\hline Transfer $(\mathrm{T})$ & 1 & $58.61^{* * *}$ & $88.96^{* *}$ & $368.29^{* * *}$ & 1 & $96.07^{* *}$ & 0.02 & $168.81^{* * *}$ & 1 & $27.09^{* * *}$ & 0.29 & $66.37^{* * *}$ & 1 & 0.49 & $73.18^{* *}$ & $129.05^{* *}$ \\
\hline $\mathrm{M} \times \mathrm{C}$ & 1 & $59.45^{* * *}$ & $30.36^{* *}$ & $110.28^{* * *}$ & 1 & $32.65^{* *}$ & 0.43 & $15.86^{*}$ & 1 & $690.68^{* * *}$ & 0.1 & $20.18^{* * *}$ & 1 & $42.15^{* *}$ & $24.9^{* * *}$ & $8.18^{*}$ \\
\hline $\mathrm{M} \times \mathrm{D}$ & 6 & $3.33^{* *}$ & $6.2^{* *}$ & $7.92^{*}$ & 8 & $24.16^{* *}$ & 1.73 & $6.28^{*}$ & 8 & $68.88^{* * *}$ & $2.85^{* *}$ & $6.41^{*}$ & 8 & $4.55^{* *}$ & $2.08^{*}$ & $3.12^{*}$ \\
\hline $\mathrm{M} \times \mathrm{T}$ & 1 & $42.62^{* * *}$ & $12.57^{* *}$ & $4.85^{*}$ & 1 & $141.07^{* *}$ & 3.77 & $10.16^{*}$ & 1 & $73.83^{* *}$ & $23.48^{* * *}$ & 3.16 & 1 & $4.16^{*}$ & 0.58 & $7.69^{*}$ \\
\hline $\mathrm{C} \times \mathrm{D}$ & 6 & 1.57 & $9.04^{* * *}$ & $5.38^{*}$ & 8 & $5.24^{* * *}$ & $2.27^{*}$ & 2.59 & 8 & $20.32^{* *}$ & $5.01^{* * *}$ & $4.61^{*}$ & 8 & $6.22^{* *}$ & $9.29^{* * *}$ & $8.69^{*}$ \\
\hline $\mathrm{C} \times \mathrm{T}$ & 1 & 0.27 & 3 & $8.36^{*}$ & 1 & $4.58^{*}$ & 0.16 & $3.88^{*}$ & 1 & 0.03 & 2.02 & $7.93^{*}$ & 1 & $4.54^{*}$ & 1.83 & $16.62^{*}$ \\
\hline $\mathrm{D} \times \mathrm{T}$ & 6 & 1.42 & 1.76 & $3.75^{*}$ & 7 & $4.69^{* * *}$ & $4.87^{* * *}$ & 1.65 & 7 & $5.74^{* * *}$ & $9.85^{* * *}$ & 2.35 & 8 & $6.32^{* * *}$ & $2.52^{*}$ & $7.36^{*}$ \\
\hline CV (\%) & & 6.96 & 7.71 & 1.52 & & 6.48 & 10.51 & 1.5 & & 5 & 9.31 & 2.22 & & 7.34 & 13.42 & 2.22 \\
\hline
\end{tabular}

${ }^{*, * *}$ Significant at $p<0.05$ or 0.01 . 


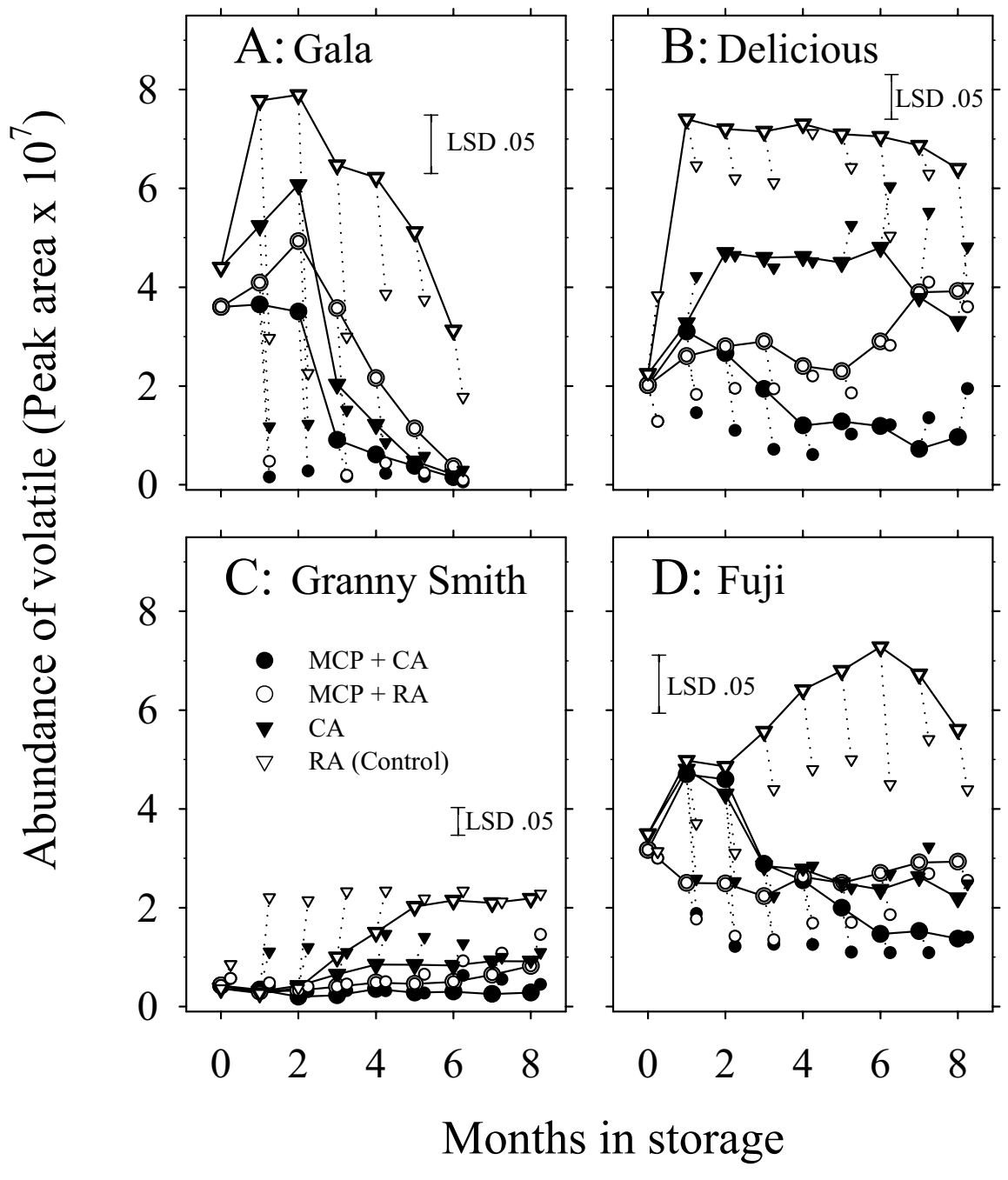

Fig. 3. Total volatile abundance of four apple cultivars treated with 1-MCP or not, and stored in CA or RA at $1{ }^{\circ} \mathrm{C}$ (solid line); subsamples were transferred to $20{ }^{\circ} \mathrm{C}$ for 1 additional week (dotted line).

An analysis of variance indicated that there were significant differences between 1-MCP pretreatment and no pretreatment, CA and RA, and among different storage durations for all of the four cultivars (Table 2). Comparisons of before and after transferring fruit to $20^{\circ} \mathrm{C}$ for 1 week showed significant differences for 'Gala', 'Delicious', and 'Granny Smith', but not 'Fuji'.

The interaction between pretreatments (1MCPvs. non-1-MCP) and storage atmospheres (CAvs. RA) was significant statistically (Table 2), but practically the combination of 1-MCP+ CA showed only a small difference in firmness compared to 1-MCP + RA for 'Gala', 'Delicious' and 'Granny Smith', and from 1-MCP + RA or CA for 'Fuji” (Fig. 1).

Titratable acidity and soluble solids. The TA decreased during $1{ }^{\circ} \mathrm{C}$ storage for ' $G a l a$ ', 'Delicious', and 'Fuji', but increased slightly in first 2 months and then decreased for 'Granny Smith' regardless of treatment (Fig. 2). Both $\mathrm{CA}$ and 1-MCP retarded the decrease in TA, although 1-MCP was more effective than $\mathrm{CA}$ for 'Gala', and 'Delicious' toward the end of storage. 1-MCP + RA was similar to CA for retarding loss of acidity in all but 'Fuji', where the 1-MCP + RA was less effective. A synergistic reaction between 1-MCP and CA was observed for 'Gala' and 'Delicious', but not for 'Granny Smith' and 'Fuji' in terms of maintaining TA (Fig. 2, Table 2).

Transferring fruit to $20{ }^{\circ} \mathrm{C}$ for 1 week accelerated TA losses for most of the cultivars and treatments (Fig. 2). The average TA loss caused by transferring fruit to $20{ }^{\circ} \mathrm{C}$ for 1 week, for control fruit over the storage duration was $14 \%, 5 \%, 12 \%$, and $11 \%$ for 'Gala', 'Delicious', 'Granny Smith', and 'Fuji', respectively. For 'Gala' and 'Granny Smith', the temperature-dependent TA loss was retarded by $\mathrm{CA}$ and/or 1-MCP, within which $1-\mathrm{MCP}$ was more effective than CA. However, for 'Delicious' and 'Fuji', CA and 1-MCP did not significantly retard TA loss (Fig. 2, Table 2). It has been reported that 1-MCP inhibited loss of TA in both pre-climacteric and climacteric apple fruit ('Fuji', 'Gala', 'Ginger Gold', 'Jonagold' and minimally for 'Delicious') (Fan et al, 1999) and in 'Golden Delicious' (Saftner et al., 2003), whereas Mir et al. (2001) saw no effect of 1-MCP in retarding decline of acid content in 'Redchief Delicious' apples, all stored in air. Watkins et al. (2000), who compared 1-MCP treated fruit in air and CA storage, reported that $1-\mathrm{MCP}$ retarded loss of acidity in air, but not CA-stored 'McIntosh', 'Empire', and 'Law Rome', and the reverse for 'Delicious'. The authors did not clearly show the effect of storage temperature (of removing fruit from cold storage to $20^{\circ} \mathrm{C}$ ) on 1-MCP maintenance of acidity, but indicated that in some cases there were storage temperature interactions. Zanella (2003) reported that 'Granny Smith' apples treated with 1-MCP maintained greater acidity during storage and following shelf life at $20^{\circ} \mathrm{C}$.

There were unique positive linear regressions between firmness and TA content for every cultivar (data not shown). For the same firmness level, 'Granny Smith' had higher TA content, and 'Fuji' had lower TA content than other cultivars (Figs. 1 and 2). Not surprisingly, there was a negative regression between TA and $\mathrm{pH}$. A small change in TA content led to a great change in $\mathrm{pH}$ for 'Fuji' fruit, but a big change in TA content led to a small response in $\mathrm{pH}$ for 'Granny Smith' apple (data not shown).

CA and 1-MCP slightly retarded the loss of SSC in 'Gala' during $1{ }^{\circ} \mathrm{C}$ storage and after transfer to $20^{\circ} \mathrm{C}$, but did not affect SSC in other cultivars (data not shown). Most of the reports show no major effects of 1-MCP or CA on SSC (DeLong et al., 2004; Fan et al.,1999; Rupasinghe et al., 2000; Zanella, 2003). However, Watkins et al. (2000) found that 1-MCP lowered SSC levels in 'McIntosh' and 'Delicious' apples in both air and CA storage, and in 'Law Rome' in CA, but had no effect on 'Empire',

Volatile abundance. There was much less total volatile production from fruit treated with 1-MCP and CA compared with that of the control (RA-stored fruit) throughout the entire $1{ }^{\circ} \mathrm{C}$ storage and after transfer to $20^{\circ} \mathrm{C}$ for all four cultivars (Fig. 3). Volatile abundance of fruit in RA increased within the first 2 months then decreased in 'Gala', continued to increase until the sixth month in 'Fuji' (Fig. 3A and D) or remained at the same level in 'Delicious' during storage at $1{ }^{\circ} \mathrm{C}$ (Fig. 3B). Volatiles did not increase until the third to fourth month in 'Granny Smith' and remained level (Fig. 3C). The increase of volatiles indicates that the fruit continued ripening during storage, and the subsequent decrease indicates that the fruit were undergoing senescence. Mattheis et al. (1998) reported similar patterns of 'Gala' volatile production during storage. However, there were significant reductions of total volatile abundance after transferring fruit from $1^{\circ} \mathrm{C}$ to $20{ }^{\circ} \mathrm{C}$ for 'Gala', 'Delicious', and 'Fuji', but not 'Granny Smith' (Fig. 3). Volatile accumulation, as measured in this study, depends on the production of volatiles by the fruit in relation to loss of volatiles due to off-gassing from (or diffusing out of) the fruit. Since transferring apples from $1{ }^{\circ} \mathrm{C}$ to $20{ }^{\circ} \mathrm{C}$ usually increases metabolism and the production of volatiles, the decreased volatile levels at $20^{\circ} \mathrm{C}$ may have been due to increased diffusion of volatiles out of the fruit. 'Gala', 'Delicious', and 'Fuji' apples produce mostly esters, as opposed to 'Granny Smith', which produces a majority of alcohols (Bai et al., 2002). According to Henry's Law, esters diffuse more readily than alcohols out of the fruit (Bai et al., 2002). 
The magnitude of volatile inhibition by 1-MCP alone (1-MCP + RA) was generally similar to that of $\mathrm{CA}$ during storage at $1{ }^{\circ} \mathrm{C}$, except for 'Delicious' until late storage (Fig. 3). However, total volatile abundance in 1-MCPpretreated fruit was often similar to or lower than that of fruit stored in CA after transfer to $20^{\circ} \mathrm{C}$ (Fig. 3). Inhibition of total volatile abundance by the 1-MCP + CA combination treatment was the most severe compared to either treatment alone (Fig. 3).

$\mathrm{CA}$ and modified atmosphere (MA) decrease volatile production of apples (Mattheis et al., 1998; Patterson et al., 1974). Production of lipid-derived volatiles is inhibited by reduced $\mathrm{O}_{2}$ levels, while volatiles that arise from amino acid catabolism are negatively impacted by elevated $\mathrm{CO}_{2}$ (Brackmann et al., 1993; Fellman et al., 2000). The mechanism of how 1-MCP inhibits volatile production is not yet clear, but in many cultivars of apple, 1-MCP inhibits production of volatiles (DeEll et al., 2005; Fan et al., 1999, 2001; Fan and Mattheis, 1999; Lurie et al., 2002; Rupasinghe et al., 2000) perhaps through inhibition of ethylene production and related events. Aroma production during fruit ripening is considered to be an ethylene-mediated response (Abeles et al., 1992), as evidenced by reduced aroma in 1-MCP-treated plums, and by the fact that propylene application restored aroma (Abdi et al., 1998). To compare the performance of $1-\mathrm{MCP}$ treatment and CA storage, more information is needed about the inhibition of 1-MCP and $\mathrm{CA}$ on volatile production in relation to apple cultivar, 1-MCP exposure (dosage, duration and temperature) and CA condition.

\section{Conclusion}

1-MCP with and without CA was tested on 'Gala', 'Delicious', 'Granny Smith', and 'Fuji' apples at levels now used commercially, to determine individual and interactive effects on eating quality factors during cold storage and subsequent simulated marketing conditions. There were significant differences found for firmness, TA and volatile abundance among the apple fruits treated with and without 1-MCP, stored in CA versus RA, over storage time, and before and after transfer to marketing temperature. In comparison with CA, 1-MCP+ RA treatments were more effective in prolonging storage life as indicated by maintenance of firmness and TA in all cultivars except 'Fuji'. In agreement with Watkins et al. (2000), results showed that a combination of $1-\mathrm{MCP}+\mathrm{CA}$ was more effective than either individual treatment alone for maintaining firmness, but our study showed this was at the expense of the highest aroma volatile losses. Therefore, 1-MCP $+\mathrm{RA}$ may be a practical alternative to CA storage of apples, while maintaining optimal flavor quality for some cultivars.

\section{Literature Cited}

Abdi, N., W.B. McGlasson, P. Holford, M. Williams, and Y. Mizrahi. 1998. Response of climacteric and suppressed-climacteric plums to treatment with propylene and 1-methylcylcopropene. Postharvest Biol. Technol. 14:29-39.

Abeles, F.W., P.W. Morgan, and M.E. Saltveit. 1992. Ethylene in plant biology. Academic Press, New York.

Bai, J., E.A. Baldwin, R.C. Soliva-Fortuny, J.P. Mattheis, R. Stanley, C. Perera, and J.K. Brecht. 2004. Effect of pretreatment of intact 'Gala' apple with ethanol vapor, heat or 1-methylcyclopropene on quality and shelf life of fresh-cut slices. J.Amer. Soc. Hort. Sci. 129:583-593.

Bai, J., R.H. Hagenmaier, and E.A. Baldwin. 2002. Volatile response of four apple varieties with different coatings during marketing at room temperature. J. Agr. Food Chem. 50:7660-7668.

Brackmann, A., J. Streif, and F. Bangerth. 1993. Relationship between a reduced aroma production and lipid metabolism of apples after long-term controlled-atmosphere storage. J. Amer. Soc. Hort. Sci. 118:243-247.

Blankenship, S.M. and J.M. Dole. 2003. 1-Methylcyclopropene: A review. Postharvest Biol. Technol. 28:1-25.

DeEll, J.R., D.P. Murr, M.D. Porteous, and H.P.V. Rupasinghe. 2002. Influence of temperature and duration of 1-methylcyclopropene (1-MCP) treatment on apple quality. Postharvest Biol. Technol. 24:349-353.

DeEll, J.R., D.P. Murr, L. Wiley, and R. Mueller. 2005. Interactions of 1-MCP and low oxygen CA storage on apple quality. Acta Hort. (n press).

DeLong, J.M., R.K. Prange, and P.A. Harrison. 2004. The influence of 1-methylcyclopropene on 'Cortland' and 'McIntosh' apple quality following long-term storage. HortSci. 39:1062-1065.

Fan, X., L. Argenta, and J.P. Mattheis. 2001. Impacts of ionizing radiation on volatile production by ripening Gala apple fruit. J. Agr. Food Chem. 49:254-262

Fan, X., S.M. Blankenship, and J.P. Mattheis. 1999. 1-Methylcyclopropene inhibits apple ripening. J. Amer. Soc. Hort. Sci. 124:690-695.

Fan, X., and J.P. Mattheis. 1999. Impact of 1methylcyclopropene and methyl jasmonate on apple volatile production. J. Agr. Food Chem. 47:2847-2853.

Fellman, J. K., T.W. Miller, D.S. Mattinson, and J.P. Mattheis. 2000. Factors that influence biosynthesis of volatile flavor compounds in apple fruits. HortScience 35:1026-1033.

Gong, Y., X. Fan, and J.P. Mattheis. 2002. Responses of 'Bing' and 'Rainier' sweet cherries to ethylene and 1-methylcyclopropene. J. Amer. Soc. Hort. Sci. 127:831-835

Jayanty, S.S., M. Canoles, and R.M. Beaudry. 2004. Concentration dependence of 'Redchief Delicious' apple fruit softening and chlorophyll fluorescence to repeated doses of 1-methylcyclopropene. J. Amer. Soc. Hort. Sci. 129:760-765.

Jiang, Y.M. and D.C. Joyce. 2002. 1-Methylcyclopropene treatment effects on intact and fresh-cut apple. J. Hort. Sci. Biotechnol. 77:19-21.

Kupferman, E. 2003. Controlled atmosphere storage of apples and pears. Acta Hort. 600:729-735.

Lurie, S., C. Pre-Aymard, U. Ravid, O. Larkov, and E. Fallik. 2002. Effect of 1-methylcyclopropene on volatile emission and aroma in Anna apples. J. Agr. Food Chem. 50:4251-4256.
Mattheis, J.P., D.A. Buchanan, and J.K. Fellman. 1998. Volatile compounds emitted by 'Gala' apples following dynamic atmosphere storage. J. Amer. Soc. Hort. Sci. 123:426-432.

Mir, N.A., E. Curell, N. Khan, M. Whitaker, and R.M. Beaudry. 2001. Harvest maturity, storage temperature and 1-MCP application frequency alter firmness retention and chlorophyull fluorescence of 'Red Delicious' apples. J. Amer. Soc. Hort. Sci. 126:618-624.

Patterson, B.D., S.G.S. Hatfield, and M. Knee. 1974. Residual effects of controlled atmosphere storage on the production of volatile compounds by two varieties of apples. J. Sci. Food Agr. 25:843-849

Plotto, A., A.N. Azarenko, M.R. McDaniel, P.W. Crockett, and J.P. Mattheis. 1997. Eating quality of 'Gala' and 'Fuji' apples from multiple harvests and storage durations. HortScience 32:903-908.

Rupasinghe, H.P.V., D.P. Murr, G. Paliyath, and L. Skog. 2000. Inhibitory effect of 1-MCP on ripening and superficial scald development in 'McIntosh' and 'Delicious' apples. J. Hort. Sci. Biotechnol. 75:271-276.

Saftner, R. A., J.A. Abbott, C.L. Barden, and W.S. Conway. 2003. Effect of 1-methylcyclopropene and heat treatments on ripening and pathogen-induced decay development in 'Golden Delicious' apples. J. Amer. Soc. Hort. Sci. 128:120-127.

Sisler,E.C., E. Dupille, and M. Serek. 1996. Effect of 1methylcyclopropene and methylenecyclopropane on ethylene binding and ethylene action on cut carnations. Plant Growth Regulat. 18:79-86.

Sisler, E.C. and M. Serek. 1999. Compounds controlling the ethylene receptor. Bot. Bul. Acad. Sin. 40:1-7.

Sisler, E.C. and C. Wood. 1988. Competition of unsaturated compounds with ethylene for binding and action in plants. Plant Growth Regulat. 7:181-191.

U.S. Environmental Protection Agency. 2002. 1-Methylcyclopropene; Exemption from the Requirement of a Tolerance. Fed. Reg. 67:48796-48800.

Watkins, C.B., E. Kupferman, and D.A. Rosenberger. 2004. Apple. In: K.C. Gross, C.Y. Wang, and M. Saltveit (ed.). The commercial storage of fruits, vegetables, and florist and nursery stocks. http:// www.ba.ars.usda.gov/hb66/027apple.pdf

Watkins, C.B. and W.B. Miller. 2004. A summary of physiological processes or disorders in fruits, vegetables and ornamental products that are delayed or decreased, increased, or unaffected by application of 1-methylcyclopropene (1-MCP). http://www.hort.cornell.edu/department/faculty/ watkins/ethylene/ethylene.index.htm.

Watkins, C.B., J.F. Nock, and B.D. Whitaker. 2000. Responses of early, mid and late season apple cultivars to postharvest application of 1-methylcyclopropene (1-MCP) under air and controlled atmosphere storage conditions. Postharvest Biol. Technol. 19:17-32.

Williams, M.W. and M.E. Patterson. 1962. Internal atmospheres in Bartlett pears stored in controlled atmospheres. Proc. Amer. Soc Hort. Sci. 81:129-136.

Zanella, A. 2003. Control of apple superficial scald and ripening-A comparison between 1-methylcyclopropene and diphenylamine postharvest treatments, initial low oxygen stress and ultra low oxygen storage. Postharvest Biol. Technol. 27:69-78. 